\title{
Macroscopic examination of fetal appendices in delivery room: good practice at Panzi hospital
}

\author{
Boengandi Walala D. ${ }^{1 *}$, Nyakio Ngeleza O. ${ }^{1}$, Mukanire Ntakwinja B. ${ }^{1}$, Raha Maroyi K. ${ }^{1}$, \\ Katenga Bosunga G. ${ }^{2}$, Mukwege Mukengere D. ${ }^{1}$
}

\begin{abstract}
${ }^{1}$ Department of Gynecology and Obstetrics, Panzi Hospital, School of Medicine, Evangelical University in Africa, Bukavu, DR Congo

${ }^{2}$ Department of Gynecology and Obstetrics, Kisangani University Clinics, School of Medicine, Kisangani University, Kisangani, DR Congo
\end{abstract}

Received: 14 January 2020

Revised: 20 February 2020

Accepted: 28 February 2020

\section{*Correspondence:}

Dr. Boengandi Walala D.,

E-mail: boengandiwalala@gmail.com

Copyright: (C) the author(s), publisher and licensee Medip Academy. This is an open-access article distributed under the terms of the Creative Commons Attribution Non-Commercial License, which permits unrestricted non-commercial use, distribution, and reproduction in any medium, provided the original work is properly cited.

\begin{abstract}
The review of fetal appendices is described in the literature, and its importance is well established. Indeed, pathological findings in the placenta can provide information on the pathogenesis of the fetus, including intrauterine growth retardation, mental retardation or neurodevelopmental disorders. This helps to understand a child's disability, but also maternal complications such as preeclampsia. Despite the relevant information provided by the various studies, fetal appendices are not systematically examined in several maternity hospitals in our country, DR Congo. We report good practice from the examination of fetal appendices to the maternity ward of Panzi Hospital, in the town of Bukavu, South Kivu, DR Congo.
\end{abstract}

Keywords: Examination, Fetal appendices, Good practice, Panzi hospital

\section{INTRODUCTION}

\section{Definition of good practice}

Good practice is not just a practice which is good, but one that is proven and successful, and is therefore recommended as a model. It is a successful experiment, tested and validated, in the broad sense, repeated, which deserves to be shared so that a greater number of people are appropriating it. ${ }^{1}$

\section{Characteristics of the fetal appendices}

Fetal appendices are temporary formations designed to protect, nourish and oxygenate the embryo and the fetus during intrauterine life and will be eliminated at the time of birth. They have a proper evolution and include: placenta, umbilical cord, membranes and amniotic fluid. ${ }^{2}$

The placenta is one of the elements of the fœto-maternal unit easily accessible after delivery and whose examination makes it possible to understand the pathology presented by the newborn. Macroscopic examination of the placenta is systematic in the birth room by the midwife and the obstetrician. In the case of maternal, fetal or placental pathology, histopathological examination of the placenta is necessary. However, this examination is most often undervalued and unused to understand the perinatal pathology. The characterization of placental lesions can provide major elements for the etiological diagnosis of preterm delivery, intrauterine growth retardation, in utero fetal death, delayed 
psychomotor development of the child. In the context of twin pregnancies, this examination makes it possible to assess the chronicity and complications of twin pregnancies. It identifies situations at risk of recurrence, allowing the establishment of a preventive treatment. Finally, it can have forensic implications, especially concerning the etiology of psychomotor development delays. A relevant examination of the placenta, integrated into a multidisciplinary approach with obstetricians and paediatricians, should make it possible to identify new anatomo-clinical entities, to better understand their pathophysiological mechanisms and to propose new treatments in serious, often recurrent neonatal pathologies. $^{3}$

The umbilical cord is a funicular stem, whitish, bumpy, surrounded by a sheath: the extension of the amnion. Inside is a mesenchymal support tissue, avascular and rich in polysaccharides, which is the Wharton jelly, in which an umbilical vein runs around which two umbilical arteries are wound. ${ }^{2}$ In case of abnormalities, only one umbilical artery is known to be associated with intrauterine growth retardation, as well as cardiac and renal malformations. ${ }^{4}$ In contrast, the number of vessels in the umbilical cord can increase by three to four. It is more common to encounter a fourth accessory vessel of the umbilical cord than a single umbilical artery. ${ }^{5}$

Although a supernumerary umbilical vein is associated with a very high incidence of congenital abnormalities, several isolated cases of very rare supernumerary umbilical cord (two arteries and two veins) presented no fetal abnormalities. ${ }^{6,7}$ The amniotic fluid surrounds the fetus throughout the life of the womb. It plays an essential protective role by protecting the fetus against external traumatisms by a buffer role and by providing a space with low resistance and maintaining the expansion of the uterine cavity, fetal mobility, essential for fetal development, particular of musculoskeletal, cardiopulmonary and digestive systems. In addition, it has antibacterial properties and provides lubrication, preventing the appearance of amniotic flanges. Amniotic fluid volume is an essential indicator of fetal well-being. Volume abnormalities, whether lack of amniotic fluid (oligoamnios) or excess amniotic fluid (hydramnios), are potential signs of fetal or maternal pathology, and are strongly correlated an increase in fetal mortality and morbidity, even in the absence of associated malformations. ${ }^{8}$

The membranes consist of the interior to the outside by: amnion, smooth chorio, parietal deciduous and reflected deciduous fused. During the third trimester, considering a constant osmotic deficit of the amniotic fluid compared to maternal plasma of 30 milliosmoles per kilogram, the net flow of exchanges is an exit of the liquid from the amniotic cavity to the mother of 0.3 to 0.7 millilitres per hour (transmembrane route). Prolactin plays a major role in the regulation of these associated exchanges. ${ }^{8}$

\section{Potential abnormalities of fetal appendices ${ }^{9}$}

Evaluating placental completeness is of critical, immediate importance in the delivery room. Retained placental tissue is associated with postpartum hemorrhage and infection. The maternal surface of the placenta should be inspected to be certain that all cotyledons are present. Then the fetal membranes should be inspected past the edges of the placenta.

Large vessels beyond these edges indicate the possibility that an entire placental lobe (e.g., succenturiate or accessory lobe) may have been retained. All or part of the placenta is retained in placenta accreta, placenta increta and placenta percreta. In these conditions, the placental tissues grow into the myometrium to lesser or greater depths. Manual exploration and the removal of retained placental tissue are necessary in these cases (Table 1).

Table 1: Placental completeness.

\begin{tabular}{|c|c|c|}
\hline Condition & Appearance & Clinical significance \\
\hline \multirow{2}{*}{$\begin{array}{l}\text { Intact, } \\
\text { complete }\end{array}$} & \multirow{2}{*}{$\begin{array}{l}\text { All cotyledons } \\
\text { present }\end{array}$} & No apparent retained placental fragments. \\
\hline & & No velamentous vessels; vessels taper to periphery of placenta. \\
\hline \multirow{3}{*}{ Incomplete } & $\begin{array}{l}\text { Cotyledons } \\
\text { missing }\end{array}$ & $\begin{array}{l}\text { Probable retained placental tissue (for example in cases of placental insertion } \\
\text { abnormalities). }\end{array}$ \\
\hline & \multirow{2}{*}{$\begin{array}{l}\text { Velamentous } \\
\text { vessels present }\end{array}$} & $\begin{array}{l}\text { Probable retained placental tissue (for example in cases of retained succenturiate lobe } \\
\text { of placenta). }\end{array}$ \\
\hline & & Retained tissue is associated with postpartum hemorrhage and infection. \\
\hline
\end{tabular}

Placentas less than $2.5 \mathrm{~cm}$ thick are associated with intrauterine growth retardation of the fetus. Placentas more than $4 \mathrm{~cm}$ thick have an association with maternal diabetes mellitus, fetal hydrops (of both immune and nonimmune etiology) and intrauterine fetal infections. An extremely thin placenta may represent placenta membrane. In this condition, the entire uterine cavity is lined with thin placenta. Placenta membrane is associated with a very poor fetal outcome (Table 2). Extra placental lobes are important, primarily because they may lead to retained placental tissue. Blood may be adherent to the maternal surface of the placenta, particularly at or near 
the margin. If the blood is rather firmly attached, and especially if it distorts the placenta, it may represent an abruption. The dimensions and volume of the placenta should be estimated (Table 3). The placenta should be palpated, and the fetal and maternal surfaces should be carefully examined.

Table 2: Placental size.

\begin{tabular}{|c|c|c|}
\hline Condition & Appearance & Clinical significance \\
\hline Normal & $\begin{array}{l}\text { Diameter: about } 20-22 \mathrm{~cm} \\
\text { Thickness in the center: } 2-3 \mathrm{~cm} \\
\text { Weight: about } 500 \text { grams }\end{array}$ & 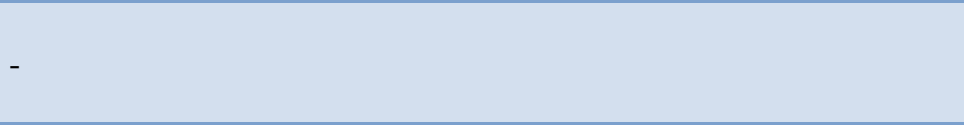 \\
\hline $\begin{array}{l}\text { Thin } \\
\text { placenta }\end{array}$ & $\begin{array}{l}\text { Less than } 2 \mathrm{~cm} \text { thick in the } \\
\text { center }\end{array}$ & $\begin{array}{l}\text { Possible placental insufficiency with intrauterine growth retardation. } \\
\text { Placenta membrane: A rare condition in which the placenta is } \\
\text { abnormally thin and spread out over a large area of the uterine wall; } \\
\text { associated with bleeding and poor fetal outcome. }\end{array}$ \\
\hline $\begin{array}{l}\text { Thick } \\
\text { placenta }\end{array}$ & $\begin{array}{l}\text { More than } 4 \mathrm{~cm} \text { thick in the } \\
\text { center }\end{array}$ & $\begin{array}{l}\text { Maternal diabetes mellitus fetal hydrops. } \\
\text { Intrauterine fetal infections (syphilis, toxoplasmosis, maternal-fetal } \\
\text { iso-immunization) }\end{array}$ \\
\hline
\end{tabular}

Table 3: Abnormalities of shape.

\begin{tabular}{|lll|}
\hline $\begin{array}{l}\text { Condition } \\
\begin{array}{l}\text { Multiple lobes (bilobate, bipartite, } \\
\text { succenturiate, accessory) }\end{array}\end{array}$ & Appearance & Clinical significance \\
\hline Placenta membrane & - & $\begin{array}{l}\text { Probable retained placenta, with surgical removal required. } \\
\text { Increased incidence of postpartum infection and hemorrhage. }\end{array}$ \\
\hline $\begin{array}{l}\text { Placenta accreta and placenta } \\
\text { percreta }\end{array}$ & - & Hemorrhage and poor fetal outcomes. \\
\hline
\end{tabular}

Table 4: Abnormalities of the maternal placental surface and substance.

\begin{tabular}{|c|c|c|}
\hline Condition & Appearance & Clinical significance \\
\hline \multirow{2}{*}{ Placental infarcts } & Firm pale or gray areas & $\begin{array}{l}\text { Old infarcts; } \\
\text { Pregnancy-induced hypertension; } \\
\text { Systemic lupus erythematosus; } \\
\text { Advanced maternal age. }\end{array}$ \\
\hline & Dark areas & $\begin{array}{l}\text { Fresh infarcts; } \\
\text { Pregnancy-induced hypertension; } \\
\text { Systemic lupus erythematosus; } \\
\text { Advanced maternal age. }\end{array}$ \\
\hline Fibrin deposition & Firm gray areas & $\begin{array}{l}\text { No clinical significance unless extensive, in which case } \\
\text { there may be placental insufficiency with intrauterine } \\
\text { growth retardation or other poor fetal outcome. }\end{array}$ \\
\hline \multirow{2}{*}{$\begin{array}{l}\text { Placental bleeding } \\
\text { (for example } \\
\text { abruption) }\end{array}$} & $\begin{array}{l}\text { Clot, especially an adherent clot } \\
\text { toward the center of the placenta, } \\
\text { with distortion of placental shape }\end{array}$ & Associated with abruption. \\
\hline & $\begin{array}{l}\text { Fresh clot located along the } \\
\text { margin, with no distortion of } \\
\text { placental shape }\end{array}$ & $\begin{array}{l}\text { Marginal hematoma: no clinical significance if the clot is } \\
\text { small. }\end{array}$ \\
\hline Chorioangioma & Fleshy, dark red & $\begin{array}{l}\text { If small: probably of no clinical significance. } \\
\text { If large: may be associated with fetal hydrops, fetal } \\
\text { anemia, thrombocytopenia, hydramnios, intrauterine } \\
\text { growth retardation, prematurity and stillbirth. }\end{array}$ \\
\hline Choriocarcinoma & Resembles a fresh infarct & Very rare with a normal gestation. \\
\hline Hydatidiform mole & $\begin{array}{l}\text { Grape-like cluster of edematous } \\
\text { villi }\end{array}$ & Very rare with a normal gestation. \\
\hline $\begin{array}{l}\text { Apparent hemorrhage } \\
\text { on the membranes or } \\
\text { a dark cyst }\end{array}$ & & $\begin{array}{l}\text { May represent the Breus mole (massive, subchorionic } \\
\text { hematoma, formed in the pregnant uterus); associated } \\
\text { with Turner's syndrome }(45, \mathrm{X}) \text { and the death of the } \\
\text { fetus. }\end{array}$ \\
\hline
\end{tabular}


Table 5: Abnormalities of the fetal placental surface.

\begin{tabular}{|c|c|c|}
\hline Condition & Appearance & Clinical significance \\
\hline Fetal anemia & Pale fetal surface & $\begin{array}{l}\text { Anemia in new-born. } \\
\text { Fetal hydrops. } \\
\text { Hemorrhage requiring transfusion. }\end{array}$ \\
\hline Circumvallate placenta & Thick ring of membranes & $\begin{array}{l}\text { Prematurity; } \\
\text { Prenatal bleeding; } \\
\text { Abruption; } \\
\text { Multiparity; } \\
\text { Early fluid loss. }\end{array}$ \\
\hline $\begin{array}{l}\text { Circummarginate } \\
\text { placenta }\end{array}$ & $\begin{array}{l}\text { Inner membrane ring thinner than } \\
\text { circumvallate placenta }\end{array}$ & $\begin{array}{l}\text { Probably of no clinical significance, but } \\
\text { may be associated with an increase in } \\
\text { fetal malformations. }\end{array}$ \\
\hline Amnion nodosum & Multiple tiny white, gray or yellow nodules & $\begin{array}{l}\text { Oligohydramnios; } \\
\text { Renal agenesis; } \\
\text { Pulmonary hypoplasia. }\end{array}$ \\
\hline Squamous metaplasia & $\begin{array}{l}\text { Multiple tiny white, gray or yellow nodules, } \\
\text { especially around the cord insertion }\end{array}$ & $\begin{array}{l}\text { Common a probably of no clinical } \\
\text { significance }\end{array}$ \\
\hline $\begin{array}{l}\text { Fetus papyraceus and } \\
\text { fetus compresses }\end{array}$ & One or several nodules or thickenings & $\begin{array}{l}\text { Deceased twin. } \\
\text { May be associated with otherwise } \\
\text { unexplained fetal demise. }\end{array}$ \\
\hline Amniotic bands & Delicate or robust bands of amnion & $\begin{array}{l}\text { Amputation of fetal parts (fingers, whole } \\
\text { limbs, head, neck, trunk); } \\
\text { Fetal death. }\end{array}$ \\
\hline
\end{tabular}

\section{Maternal surface}

In a term infant without anemia, the maternal surface of the placenta should be dark maroon. In a premature infant, the placenta is lighter in color. Pallor of the maternal surface indicates the presence of fetal anemia, which may be a sign of hemorrhage. With prompt recognition of fetal hemorrhage (such as occurs in vasa previa), lifesaving transfusion can be performed. Clots on the maternal surface, particularly adherent centrally located clots, may represent placental abruption. It should be emphasized, however, that abruption is a clinical diagnosis (Table 4).

Numerous small, firm, white, gray or yellow nodules on the fetal surface may represent either amnion nodosum or squamous metaplasia. Amnion nodosum is associated with oligohydramnios, renal agenesis and poor fetal outcome. Squamous metaplasia is common and is probably of no fetal significance. A nodule or thickening on the fetal surface may represent a vanished twin or a fetus papyraceus. A deceased twin sometimes coexists with a normal fetus, but it may also be associated with demise of the second twin, and this second death may be of uncertain cause. Delicate or more robust bands of amnionic tissue may strangle and amputate fetal parts, including digits, entire limbs, head, neck or trunk. In such cases, amnion may be missing from the placenta but present on the cord. When fetal parts are missing or amputated, careful pathologic examination of the placenta is warranted (Table 4).

\section{Placental parenchyma}

A diffusely soft placenta may represent infection, particularly if the structure is also thickened. Firm areas in the placenta may represent fibrin deposition or infarction. Fresh infarcts are red, while older infarcts are gray. Fibrin deposits are gray and, if extensive, may be associated with intrauterine growth retardation and other poor fetal outcomes. If infarcts or fibrin occupy less than 5 percent of the placental mass, they are usually unimportant. Focal fleshy, dark-red areas may represent chorioangiomas. These benign hemangiomas occur in 1 percent of placentas. While small chorioangiomas are usually of no clinical significance, large chorioangiomas are associated with fetal anemia, thrombocytopenia, hydrops, hydramnios, intrauterine growth retardation, prematurity and stillbirth. Gestational trophoblastic neoplasia, including benign hydatidiform moles, invasive moles and choriocarcinoma, only rarely coexist with viable gestations. Moles appear as grape-like clusters of edematous villi, while choriocarcinoma may look much like an infarct. Apparent hemorrhage deep to the fetal membranes or a dark-colored cyst may represent Breus' mole, which is associated with Turner's syndrome $(45, \mathrm{X})$ and with fetal demise. Any suspicious specimen must be examined by a pathologist, with follow-up as indicated by the disease process (Table 4).

A thick ring of membranes on the fetal surface of the placenta may represent a circumvallate placenta, which is associated with prematurity, prenatal bleeding, abruption, multiparity and early fluid loss. A similar but thinner ring 
of membrane tissue represents a circummarginate placenta. A circummarginate placenta is probably of no clinical significance, although one study found an association between this structural anomaly and an increase in fetal malformations (Table 5).

Table 6: Abnormalities of the umbilical cord.

\begin{tabular}{|c|c|c|}
\hline Condition & Appearance & Clinical significance \\
\hline Cord length & $\begin{array}{l}\text { Measure the length and include the } \\
\text { fetal and maternal ends (normal } \\
\text { length: about } 35 \text { to } 75 \mathrm{~cm} \text { ) }\end{array}$ & 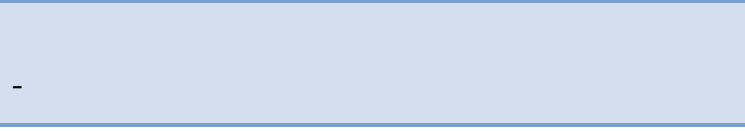 \\
\hline Short cord & Less than $35 \mathrm{~cm}$ & $\begin{array}{l}\text { Poorly active fetus } \\
\text { Down syndrome (or trisomy } 21 \text { ); } \\
\text { Werdnig-Hoffmann's disease (or anterior spinal } \\
\text { muscular atrophy); } \\
\text { Decreased in intelligence quotient; } \\
\text { Fetal malformations; } \\
\text { Myopathic and neuropathic disease; } \\
\text { Cord rupture, hemorrhage or stricture; } \\
\text { Breech or other fetal malpresentation; } \\
\text { Prolonged second stage of labor; } \\
\text { Abruption; } \\
\text { Uterine inversion }\end{array}$ \\
\hline Long cord & More than $75 \mathrm{~cm}$ & $\begin{array}{l}\text { Fetal hyperkinesis; } \\
\text { Increased risk of fetal entanglement; } \\
\text { Increased risk of torsion and knots; } \\
\text { Thromboses. }\end{array}$ \\
\hline $\begin{array}{l}\text { Thin cord and decreased } \\
\text { amount of Wharton's } \\
\text { jelly }\end{array}$ & $\begin{array}{l}\text { Narrow areas in the cord (normal } \\
\text { cord has a relatively uniform } \\
\text { diameter of } 2 \text { to } 2.5 \mathrm{~cm} \text { ) }\end{array}$ & $\begin{array}{l}\text { Post-maturity and oligohydramnios; } \\
\text { Torsion and fetal death }\end{array}$ \\
\hline \multirow[t]{2}{*}{ Edema } & Diffuse & $\begin{array}{l}\text { Hemolytic disease; Prematurity; } \\
\text { Cesarean section; } \\
\text { Maternal preeclampsia; Eclampsia; } \\
\text { Maternal diabetes mellitus; Transient tachypnea of } \\
\text { the newborn; } \\
\text { Idiopathic respiratory distress. }\end{array}$ \\
\hline & Focal & $\begin{array}{l}\text { Trisomy } 18 \text { syndrome; } \\
\text { Patent urachus; } \\
\text { Omphalocele. }\end{array}$ \\
\hline Necrotizing funisitis & $\begin{array}{l}\text { Distinctive segmental resemblance } \\
\text { to a barber's ; Possible swelling, } \\
\text { necrosis, thrombosis and possible } \\
\text { calcifications }\end{array}$ & $\begin{array}{l}\text { Syphilis and other acute, subacute and chronic } \\
\text { infections. }\end{array}$ \\
\hline $\begin{array}{l}\text { Velamentous cord } \\
\text { insertion }\end{array}$ & & $\begin{array}{l}\text { Increased risk of fetal hemorrhage from the } \\
\text { unprotected vessels, as well as vascular compression } \\
\text { and thrombosis; } \\
\text { Advanced maternal age; } \\
\text { Diabetes mellitus; } \\
\text { Smoking; } \\
\text { Single umbilical artery; } \\
\text { Fetal malformations. }\end{array}$ \\
\hline Cord knot & & Fetal compromise if the knot is tight. \\
\hline Entanglement & & Fetal compromise, especially at delivery. \\
\hline $\begin{array}{l}\text { Abnormal number of } \\
\text { vessels }\end{array}$ & $\begin{array}{l}\text { Expect two arteries and one vein. } \\
\text { Count the number of vessels at } \\
\text { more than } 5 \mathrm{~cm} \text { from the placental } \\
\text { end of the cord }\end{array}$ & $\begin{array}{l}\text { If only one artery is present, up to nearly a } 50 \\
\text { percent incidence of fetal anomalies (cardiovascular, } \\
\text { genitourinary, gastrointestinal systems, etc.); } \\
\text { Cord more prone to compression. }\end{array}$ \\
\hline Other thromboses & Clot in vessels on cut section & Fetal compromise. \\
\hline $\begin{array}{l}\text { Amnionic web at the } \\
\text { base of the cord }\end{array}$ & & $\begin{array}{l}\text { Fetal death (as it compromises circulation to the } \\
\text { fetus). }\end{array}$ \\
\hline
\end{tabular}




\section{Umbilical cord}

While opinions of authorities differ with regard to the limits of normal for cord length, 35 to $75 \mathrm{~cm}$ would appear to be a reasonable range. The typical umbilical cord is long enough $(55$ to $60 \mathrm{~cm})$ to allow the infant to begin nursing before placental delivery. This provides a release of oxytocin to facilitate uterine contractions and both the shearing and delivery of the placenta. In part, cord length is genetically determined. However, the length of the umbilical cord is also increased by the tension the fetus places on the cord. Hence, a short cord is associated with a less active fetus, fetal malformations, myopathic and neuropathic diseases, Down syndrome and oligohydramnios. Short cords may result in cord rupture, hemorrhage and stricture. Cords of insufficient length may also result in breech and other fetal malpresentations, a prolonged second stage of labor, abruption and uterine inversion. The umbilical cord may become excessively long because of fetal hyperkinesis. Long cords are associated with entanglements, torsion, knots and thromboses. Abnormalities of cord length are clearly associated with an array of longstanding intrauterine factors and consequences, some of which may become apparent only much later in a child's life. Hence, cord length should be documented for every delivery (Table 6).

\section{Cord diameter and inflammation}

Throughout its length, the typical umbilical cord has a fairly uniform diameter $(2.0$ to $2.5 \mathrm{~cm})$. Narrow areas may represent a focal deficiency of Wharton's jelly and are associated with torsion and fetal death. Diffuse edema of the cord is associated with hemolytic disease, prematurity, caesarean section, maternal preeclampsia, eclampsia and diabetes mellitus. Cord edema may also be associated with either transient tachypnea of the newborn or idiopathic respiratory distress syndrome. Focally edematous cords are associated with trisomy 18 syndrome, patent urachus and omphalocele. Necrotizing funisitis is a severe inflammation of the cord that sometimes has a distinctive segmental resemblance to a barber's pole. This inflammatory condition may represent syphilis or some other acute, subacute or chronic infection. Swelling, necrosis, thrombosis and calcifications may be present (Table 6).

\section{Cord insertion}

The umbilical cord typically inserts into the placenta near its center. About 90 percent of cord insertions are central or eccentric. About 7 percent of umbilical insertions occur at the placental margin. Marginal insertions are generally benign. In about 1 percent of singleton fetuses, cord insertion is velamentous. This type of cord insertion is associated with an increased risk of fetal hemorrhage from the unprotected vessels, as well as vascular compression and thrombosis. Velamentous cord insertion is also associated with advanced maternal age, diabetes mellitus, smoking, a single umbilical artery and fetal malformations (Table 6).

\section{Cord knots}

A true cord knot occurs when the fetus passes through a loop of umbilical cord, usually early in pregnancy. In most cases, a knot does not cause fetal compromise. However, if sufficient tension is placed on the cord before or during labor and delivery, blood flow may be cut off, and signs of fetal asphyxia may occur (Table 6).

\section{Cord vessels}

The umbilical cord typically contains two arteries and a single vein. If only one artery and one vein are grossly visible, the fetal anomaly rate is nearly 50 percent. 11 These anomalies may affect the cardiovascular, genitourinary or gastrointestinal system, and other systems as well (Table 6).

\section{Thromboses}

Thrombosis of cord vessels is often overlooked by both delivering physicians and pathologists. This is an important cause of fetal injury (Table 6).

\section{Table 7: Abnormalities of the membranes.}

\begin{tabular}{|c|c|c|}
\hline Condition & Appearance & Clinical significance \\
\hline Color & Green & $\begin{array}{l}\text { Meconium staining; } \\
\text { Sometimes the green color is the result of old blood from an earlier bleeding event } \\
\text { (modification of blood pigments); } \\
\text { Infection (myeloperoxidase in leukocytes). }\end{array}$ \\
\hline Smell & Malodorous & $\begin{array}{l}\text { Possible infection; } \\
\text { Fecal odor: possibly Fusobacterium or Bacteroides infection; } \\
\text { Sweet odor: possibly Clostridium or Listeria infection. }\end{array}$ \\
\hline
\end{tabular}

Fetal membranes should be thin, gray and glistening. Thick, dull, discoloured or foul-smelling membranes indicate the possibility of infection. The nature of the odor may provide a clue to the infecting organism: a fecal 
odor may indicate fusobacterium or bacteroides, while a sweet odor may indicate clostridium or listeria. Greencolored fetal membranes are frequently the result of meconium staining. However, a green color may be imparted by changing blood pigments from an earlier bleeding event or by the myeloperoxidase in leukocytes in the case of infection. Thick green slime that easily rinses off the membranes is meconium. Any other pigmentation requires histologic determination (Table 7).

\section{Our experience in examining fetal appendices}

During THIS specialty training in gynecology and obstetrics at Panzi Hospital, we found that fetal appendices were not systematically examined at birth. Therefore, the department recommended to us as subject of memory: "Morphological and biometric study of the fetal appendices in the elderly parturients, and their obstetrical implication at Panzi Hospital". This allowed us to develop a data collection pattern, and as a necessary material for the examination of the fetal appendices, it was necessary to have: a weigh for the placenta; a notebook for recording the data; a pair of scissors to cut the membranes and the umbilical cord a centimetre before weighing the placenta; a plastic basin to spread the placenta to examine the maternal surface; 3 small plastic buckets to hold the placentas before their examination or to put placentas of parturients who have undergone caesarean section, to bring them to the maternity for their examination; 3 meter tape to measure the length of the umbilical cord and the diameter of the placenta.

All gynecology and obstetrics staff were trained in the review of fetal appendices. Thus, at each delivery, the team of birth attendants and doctors systematically examined the appendices. This allowed us to discover a lot of information, including: a partially umbilical cord with four vessels (two arteries and two veins) that we published, placentas circummarginate, a placenta circumvallate, a placenta with multiple chorionic cysts, placentas with chorioangioma.

\section{CONCLUSION}

After a few minutes' examination of the fetal appendices in the delivery room, useful information is provided for immediate and subsequent management of the mother and child. The results of this assessment should be recorded in a register. Because, many discoveries, whether usual or not on fetal appendices, are associated with abnormal fetal development and perinatal morbidity. During the examination, the elements on the placenta should be noted: delivery mode, both surfaces, shape, consistency, diameter, weight, center thickness, and abnormalities. Umbilical cord components should also be evaluated: length, circumference, number of arteries, Wharton's jelly, placental insertion mode, and abnormalities. Finally, it is necessary to note the elements on the membranes: the aspect, the mode of insertion on the placenta, the large velamentous vessels and the small side of the membranes. Completeness of the placenta and membranes is essential in preventing immediate and late postpartum haemorrhage; indeed, we have seen, on several occasions, mothers who had returned home, to return to the hospital for vaginal bleeding whose etiology was the ovum remains.

It is very useful for all maternity clinics to appropriate the good practice of examining fetal appendices in their daily practice.

\section{ACKNOWLEDGMENTS}

Authors would like to thank to all gynecology and obstetrics staff who systematically examined the appendices at each delivery.

\section{Funding: No funding sources \\ Conflict of interest: None declared \\ Ethical approval: Not required}

\section{REFERENCES}

1. Food and Agriculture Organization of the United Nations. Good practices. Food and Agriculture Organisation. Rome. 2015. Available at: http://www.fao.org/knowledge/goodpractices/fr/. Accessed $14^{\text {th }}$ December 2019.

2. Schaaps JP, Thoumsin H, Hustin J et Foidart JM. Physiologie placentaire. EMC (Elsevier, Paris), Gynecol Obstet.1998;5-005-A-10:20.

3. L'Herminé-Coulomb A. Examen du placenta. Elsevier Masson. Obstet Gynecol. 2005;2:246-60.

4. Hua M, Odibo AO, Macones GA, Roehl KA, Crane JP, Cahill AG. Single umbilical artery and its associated findings. Obstet Gynecol. 2010;115(5):930-4.

5. Meyer WW, Lind J, Moinian M. An accessory fourth vessel of the umbilical cord. A preliminary study. Am J Obstet Gynecol. 1969;105:1063-8.

6. Painter D, Russell P. Four-vessel umbilical cord associated with multiple congenital anomalies. Obstet Gynecol. 1977;50:505-7.

7. Perez-Cosio C, Sheiner E, Abramowicz JS. Fourvessel umbilical cord: not always a dire prognosis. J Ultrasound Med. 2008;27:1389-91.

8. Senthiles L, Faury MN, Mahieu-Caputo D. Amniotic fluid regulation. In: Loïc M., ed Elsevier-Masson SAS. Traité d'Obstétrique. Paris; 2010:14-18.

9. Joseph F. Examination of the placenta. Am Family Physi. 1998;57(5):1045-60.

Cite this article as: Walala $\mathrm{BD}$, Ngeleza NO, Ntakwinja MB, Maroyi RK, Bosunga KG,

Mukengere MD. Macroscopic examination of fetal appendices in delivery room: good practice at Panzi hospital. Int J Reprod Contracept Obstet Gynecol 2020;9:2215-21. 